\title{
Opieka nad pacjentem w przebiegu raka płuc
}

\section{Patient care in the course of lung cancer}

MARTYNA GÓRNIEWICZ1 ${ }^{1}$ PAULINA ANTCZAK ${ }^{1}$

${ }^{1}$ Studenckie Koło Naukowe Nauk o Zdrowiu, Instytut Nauk o Zdrowiu PUZ we Włocławku, opiekun Koła: dr Beata Haor

DOI: https://dx.doi.org/10.21784/lwP.2019.024

ISSN: 2451-1846

\section{Streszczenie:}

Wstęp. Rak płuc główną przyczyna zgonów z powodu nowotworów w populacji mężczyzn. Stanowi także istotną przyczynę śmierci kobiet.

Cel. Celem pracy jest analiza wybranych aspektów opieki pielęgniarskiej nad pacjentem z chorobą nowotworową płuc.

Materiały i metody. W pracy dokonano analizy literatury poświęconej zagadnieniom opieki nad pacjentem $\mathrm{w}$ przebiegu raka płuc oraz przeprowadzono mapowanie diagnoz i interwencji pielęgniarskich przy użyciu słownika ICNP® .

Wnioski. Rak płuc istotnie modyfikuje jakość życia pacjenta. Klasyfikacja ICNP® pozwala na projektowanie opieki pielęgniarskiej w oparciu o ujednoliconą terminologię.

Słowa kluczowe: rak płuc, opieka, ICNP®

\section{Summary:}

Introduction. Lung cancer is the leading cause of cancer-related deaths in the male population. It is also a significant cause of women's death.

Aim. The aim of the study is to analyze selected aspects of nursing care for a patient with lung cancer. 
Materials and methods. The paper analyzes literature on patient care in the course of lung cancer and mapping nursing diagnoses and interventions using the ICNP® dictionary.

Conclusions. Lung cancer significantly modifies the patient's quality of life. The ICNP® classification allows you to design nursing care based on standardized terminology.

Key words: lung cancer, care, ICNP®

\section{Wstęp}

Nowotwory złośliwe znajdują się na drugim miejscu pod względem umieralności w Polsce. Szereg badań potwierdza, że kontakt $\mathrm{z}$ dymem tytoniowym ma istotny wpływ na wystąpienie wielu nowotworów, w tym raka krtani, jamy ustnej, przełyku, gardła oraz pęcherza moczowego [1]. W początkowym stadium rak płuca rozwija się bezobjawowo. Do rozpoznania choroby często dochodzi przypadkiem, gdyż dolegliwości występują późno. Wczesne wykrycie choroby daje jednak lepsze rokowanie [2].

Na rycinie 1 przedstawiono zachorowalność na raka płuc wśród mężczyzn w Polsce na przestrzeni trzech lat począwszy od roku 2014 [3-5].

Rycina 2 przedstawia zachorowalność na raka płuca wśród kobiet w Polsce na przestrzeni lat 2014-2016 [3-5]. 


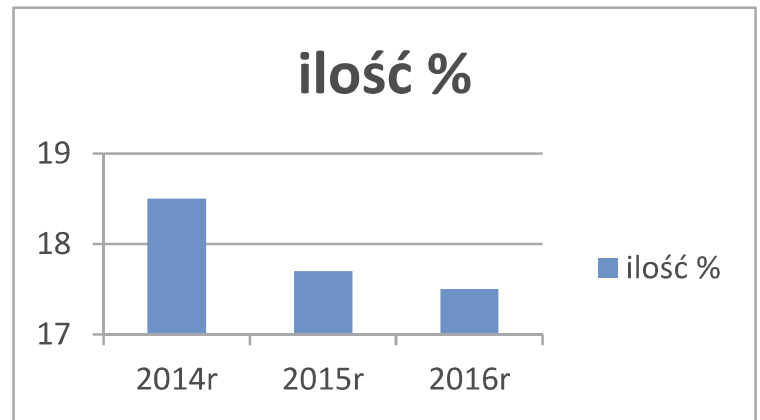

Rycina1. Zachorowalność mężczyzn na raka płuca w Polsce w latach 2014-2016 [3-5].

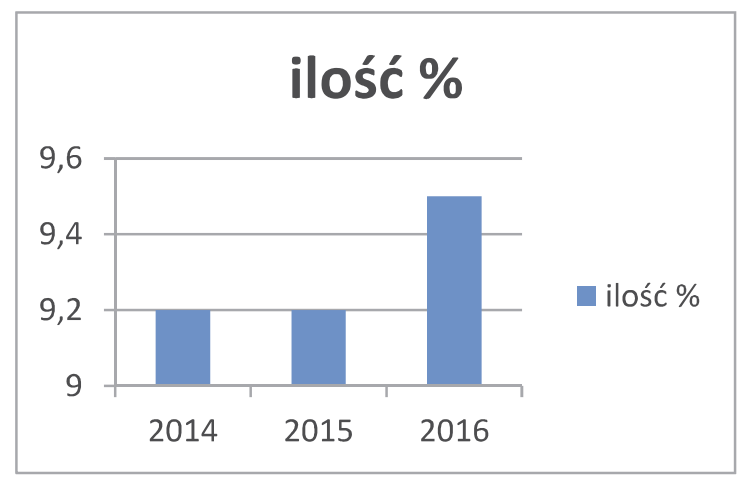

Rycina2. Zachorowalność kobiet na raka płuc $w$ Polsce $w$ latach 2014-2016[3-5]. 
W 2014 roku nowotwór płuc dotyczył 18.5\% mężczyzn oraz 9.2\% kobiet. W kolejnym roku odsetek ten w populacji męskiej wynosił 17,7\% a w żeńskiej - 9,2\%. Z kolei w 2016 roku rak płuca dotyczył 17,5\% mężczyzn oraz 9,5\% kobiet. W grupie mężczyzn największą liczbę zachorowań notuje się w przedziale 55-79 lat, natomiast u kobiet 50-79 lat [3-5].

W 2014 roku u mężczyzn najczęściej notowanym ze wszystkich nowotworów złośliwych był rak płuc (30\%). W 2015 roku odsetek ten wynosił 17,7\%, natomiast w roku 2016 - 17,6\% [35].

W populacji kobiet zachorowalność na raka płuc biorąc pod uwagę wszystkie nowotwory złośliwe w 2014 roku plasowała się na drugim miejscu, zaraz po nowotworze złośliwym piersi $(21,7 \%)$ [1]. W 2015 roku zachorowalność nie uległa zmianie, natomiast w 2016 roku dotyczyła 9,5\% kobiet [2,3].

Czynnik ryzyka nowotworu to sytuacja, która może przyczynić się bezpośrednio do jego powstania. Najważniejszym z nich jest palenie tytoniu. Dym tytoniowy w swoim składzie zawiera ponad 4000 składników: 95\% strumienia dymu tytoniowego stanowi 400-500 związków gazowych, a około 3500 to cząsteczki stałe. Podstawowym źródłem ekspozycji jest główny strumień dymu, który powstaje podczas aktywnego wdychania. Tlący się papieros naraża osoby przebywające $\mathrm{w}$ tym samym $\mathrm{w}$ pomieszczeniu na negatywne skutki palenia, oraz pogarsza jakość powietrza [1]. Tytoń jest głównym czynnikiem ryzyka nowotworów jamy ustnej i gardła, płuca, krtani i przełyku. Z kolei wśród innych czynników sprzyjających rozwojowi rakowi płuca można wyróżnić: bierne palenie tytoniu, wdychanie zanieczyszczonego powietrza, skażenia powietrza w pomieszczeniach zamkniętych [1].

Pod względem histologicznym najczęściej rozpoznawane są 4 typy: rak gruczołowy, płaskonabłonkowy, drobnokomórkowy oraz 
wielokomórkowy. Inne typy stanowią mniej niż $1 \%$ wszystkich rozpoznań pierwotnych nowotworów płuca [6].

W początkowym stadium zaawansowania rak płuc nie daje żadnych niepokojących objawów. Typowymi symptomami świadczącymi o obecności nowotworu w klatce piersiowej są: ograniczenie wydolności oddechowej, ból, krwioplucie, duszność oraz częste zapalenia płuc [6].

Nowotwór płuca rozwija się centralnie, czyli w okolicy dużych oskrzeli lub obwodowo. Raki gruczołowe występują częściej w obwodowych częściach płuc. Przerzuty najczęściej pojawiają się w węzłach chłonnych. W dalszej kolejności jest to wątroba, mózg, drugie płuco, nadnercza oraz tkanka podskórna. Zdarza się, że przerzuty występują w miejscach odległych i bez zajęcia węzłów chłonnych. Rak płuca może się szerzyć miejscowo poprzez naciekanie anatomicznych struktur śródpiersia, przepony i ściany klatki piersiowej [6].

Aby określić zaawansowanie raka płuca należy określić stan guza pierwotnego, węzłów chłonnych oraz narządów, w których pojawiły się przerzuty [6].

Leczenie nowotworu jest podejmowane $\mathrm{w}$ różnym stadium jego zaawansowania[3]. Powinno być ono zaplanowane przez zespół, który składa się z wielu specjalistów (specjalista radioterapii, onkolog kliniczny, torakochirurg, patomorfolog, pulmonolog oraz pneumonolog). Leczenie powinno odbywać się w wykwalifikowanych ośrodkach mających dostępność do współczesnych metod diagnostyki, leczenia chirurgicznego oraz systemowego. Ośrodki, w których odbywa się leczenie chorych na raka płuc powinny mieć także odpowiednie doświadczenie i możliwości stosowania leczenia skojarzonego [6].

Do podstawowych metod terapii raka płuca możemy zaliczyć: -radioterapię, 
-chemioterapię,

-leczenie operacyjne,

-leczenie skojarzone $[6,14]$.

Radioterapia jest to jedna z podstawowych metod stosowana podczas leczenia nowotworu płuca. Jej zadaniem jest zniszczenie nowotworu przy pomocy odpowiedniego promieniowania jonizującego [12]. Według danych pochodzących z Narodowego Funduszu Zdrowia w naszym kraju w latach 2005-2014 metoda ta została zastosowana u 32\% pacjentów chorujących na raka płuca [6]. Radioterapia może być samodzielnym etapem leczenia lub współdziałać z inną matodą leczenia skojarzonego, między innymi z chirurgią i chemioterapią [7]. Spowalnia ona szybkość rozrostu komórek nowotworowych.

Radioterapia może mieć również zastosowanie w leczeniu paliatywnym nowotworu płuc. Jej celem jest wówczas zmniejszenie dolegliwości bólowych pacjenta. W radioterapii paliatywnej stosowane są mniejsze dawki napromieniowania niż w leczeniu radykalnym. Jeżeli w organizmie pacjenta występują mnogie przerzuty, napromieniowaniu będą poddane tylko te zmiany, które powodują dolegliwości [12].

Współcześnie chemioterapia stanowi jedną z podstawowych metod leczenia nowotworów. Stwarza największą szansę na wyleczenie raka we wczesnych jego fazach. Może być stosowana w każdej fazie leczenia - przed i po leczeniu operacyjnym. Wykorzystywana jest także podczas radioterapii [12]. Skuteczność chemioterapii zależy między innymi od właściwego stosowania leków, które będą zmniejszały skutki uboczne leczenia[13]. Chemioterapia jest stosowana również $\mathrm{w}$ terapii paliatywnej. Pacjent leczony paliatywnie przed podaniem chemioterapii musi mieć odpowiednią wydolność układu krwiotwórczego, wątroby, nerek oraz układów sercowo-naczyniowego i oddechowego. Chorego nie powinny dotyczyć 
także powikłania innych chorób współwystępujących lub/i następstwa przebytego wcześniej leczenia przeciwnowotworowego [6].

Leczenie operacyjne należy do podstawowych metod leczenia nowotworu raka płuc. Zwykle jest ono pierwszym krokiem na długiej drodze terapii pacjenta [14]. Stwarza realną szansę powodzenia leczenia [15]. Jest ono poprzedzone pełną oceną zasięgu nowotworu [6]. Zakres wycięcia zmian nowotworowych zależy od ich rozległości oraz umiejscowienia [9]. Podczas operacji chirurdzy usuwają ognisko pierwotne guza [14]. Leczenie chirurgiczne powinno być uzupełniane pełną chemioterapią (4-6 cykli). Jeżeli w organizmie obecne są przerzuty $\mathrm{w}$ węzłach chłonnych, należy dodatkowo rozważyć radioterapię [6].

Leczenie skojarzone sprzyja większej skuteczności poszczególnych metod terapeutycznych. Polega ono na łączeniu kilku metod terapii u jednego pacjenta. Jest ono obecnie podstawą strategii postępowania terapeutycznego w onkologii. Warunkiem, który musi być spełniony, aby takie leczenie było skuteczne, jest prowadzenie nowoczesnego leczenia w wielospecjalistycznych ośrodkach onkologicznych [14].

\section{Materiał i metody}

W pracy dokonano analizy literatury poświęconej epidemiologii, aspektom klinicznym oraz założeniom opieki nad pacjentem w przebiegu raka płuc.

\section{Przegląd}


Poniżej zaprezentowano przykłady planowania opieki pielęgniarskiej wobec chorego $\mathrm{w}$ przebiegu raka płuc. Zaprezentowano problemy pacjenta $\mathrm{w}$ ujęciu klasycznym oraz dokonano mapowania diagnoz oraz interwencji pielęgniarskich przy użyciu ICNP® (wersja z 2019r.) [7].

Problem pacjenta: Ból w klatce piersiowej Diagnoza negatywna wg ICNP®: Ból [10023130] +klatka piersiowa [10019692]

\begin{tabular}{|l|l|}
\hline $\begin{array}{l}\text { Działania pielęgniarskie w ujęciu } \\
\text { klasycznym }\end{array}$ & Interwencje wg ICNP® [7] \\
\hline $\begin{array}{l}\text { ocena intensywności bólu według } \\
\text { skali NRS [8] } \\
\text { ocena bólu w skali VAS [9] }\end{array}$ & ocenianie bólu [10026119] \\
\hline $\begin{array}{l}\text { podanie leków przeciwbólowych } \\
\text { zgodnie z kartą zleceń lekarskich [8] }\end{array}$ & $\begin{array}{l}\text { administrowanie lekiem } \\
\text { przeciwbólowym [10023084] }\end{array}$ \\
\hline $\begin{array}{l}\text { zastosowanie technik } \\
\text { relaksacyjnych [9] }\end{array}$ & $\begin{array}{l}\text { używanie (wykorzystywanie) } \\
\text { techniki relaksacyjnej [10044992] } \\
\text { demonstrowanie technik } \\
\text { relaksacyjnych [10024365] }\end{array}$ \\
\hline $\begin{array}{l}\text { zwrócenie uwagi na emocjonalny } \\
\text { (niepokój oraz lęk) składnik bólu [8] }\end{array}$ & $\begin{array}{l}\text { zapewnienie wsparcia } \\
\text { emocjonalnego [10027051] }\end{array}$ \\
\hline zapewnienie bezpieczeństwa [9] & $\begin{array}{l}\text { implementacja reżimu } \\
\text { bezpieczeństwa [10036565] }\end{array}$ \\
\hline pomoc przy zmianie pozycji [8] & pozycjonowanie pacjenta \\
& {$[10014761]$} \\
\hline
\end{tabular}

Problem pacjenta: duszność nasilająca się w czasie wysiłku 
Diagnoza negatywna wg ICNP®: duszność funkcjonalna (wysiłkowa) [10029414]

\begin{tabular}{|l|l|}
\hline $\begin{array}{l}\text { Działania pielęgniarskie w ujęciu } \\
\text { klasycznym }\end{array}$ & Interwencje wg ICNP®[7] \\
\hline podawanie zleconych leków [16] & podawanie leku [10040708] \\
\hline $\begin{array}{l}\text { zastosowanie inhalacji nawilżających, } \\
\text { leczniczych [16] }\end{array}$ & terapia inhalacją [10044819]; \\
\hline $\begin{array}{l}\text { w razie potrzeby podanie tlenu [9] } \\
\text { podanie pacjentowi tlenu w sytuacji } \\
\text { nasilenia duszności [11] }\end{array}$ & terapia tlenem [10039369] \\
\hline $\begin{array}{l}\text { pomoc pacjentowi w czynnościach } \\
\text { samoobsługowych i fizjologicznych } \\
\text { [11] }\end{array}$ & asystowanie w samoopiece \\
\hline $\begin{array}{l}\text { ocena rodzaju duszności [9] } \\
\text { [10035763] }\end{array}$ \\
\hline $\begin{array}{l}\text { Zapewnienie dostępu do świeżego } \\
\text { powietrza, przewietrzenie sali } \\
\text { chorego [9] } \\
\text { utrzymanie w pomieszczeniu chorego } \\
\text { korzystnych warunków mikroklimatu } \\
\text { [11] }\end{array}$ & [100enianie statusu oddechowego \\
\hline
\end{tabular}

Problem pacjenta: niedożywienie wynikające $\mathrm{z}$ rozwoju choroby nowotworowej

Diagnoza negatywna wg ICNP®: zaburzony status odżywienia [10025746]

\begin{tabular}{|l|l|}
\hline $\begin{array}{l}\text { Działania pielęgniarskie w ujęciu } \\
\text { klasycznym }\end{array}$ & Interwencje wg ICNP®[7] \\
\hline $\begin{array}{l}\text { ocena stanu odżywienia chorego [9] } \\
\text { ustalenie zapotrzebowania na } \\
\text { składniki odżywcze i witaminy [9] }\end{array}$ & $\begin{array}{l}\text { ocenianie statusu odżywienia } \\
\text { [10030660] }\end{array}$ \\
\hline $\begin{array}{l}\text { obserwacja stanu ogólnego w } \\
\text { kierunku objawów ze strony układu }\end{array}$ & ciągły nadzór [10005093] \\
\hline
\end{tabular}




\begin{tabular}{|l|lr|}
\hline pokarmowego [16] & & \\
\hline $\begin{array}{l}\text { edukacja na temat prawidłowego } \\
\text { sposobu podawania żywienia [8] }\end{array}$ & $\begin{array}{l}\text { nauczanie } \\
{[10024618] ;}\end{array}$ & odżywianiu \\
\hline $\begin{array}{l}\text { uwzględnienie odpowiedniej podaży } \\
\text { płynów [9] }\end{array}$ & $\begin{array}{l}\text { monitorowanie } \\
\text { płynów [10035303] }\end{array}$ & przyjmowania \\
\hline $\begin{array}{l}\text { mobilizacja chorego do } \\
\text { przestrzegania pory posiłków i } \\
\text { zjadania całych porcji [9] }\end{array}$ & monitorowanie & odżywiania \\
\hline $\begin{array}{l}\text { kontrola masy ciała [16] } \\
\text { [10036032] }\end{array}$ & \\
& monitorowanie & wagi ciała \\
\hline
\end{tabular}

Problem pacjenta: ryzyko wystąpienia odwodnienia $\mathrm{z}$ powodu wymiotów

Diagnoza negatywna wg ICNP®: ryzyko odwodnienia [10041895]

\begin{tabular}{|l|l|}
\hline $\begin{array}{l}\text { Działania pielęgniarskie w ujęciu } \\
\text { klasycznym }\end{array}$ & Interwencje wg ICNP® [7] \\
\hline $\begin{array}{l}\text { stosowanie leków } \\
\text { przeciwwymiotnych [10] }\end{array}$ & $\begin{array}{l}\text { administrowanie lekiem } \\
{[10025444] ;}\end{array}$ \\
\hline $\begin{array}{l}\text { obserwacja pacjenta, czy się nie } \\
\text { odwadnia [10] }\end{array}$ & $\begin{array}{l}\text { monitorowanie przyjmowania } \\
\text { płynów [10035303] }\end{array}$ \\
\hline $\begin{array}{l}\text { utrzymanie właściwej higieny jamy } \\
\text { ustnej [10] } \\
\text { toaleta jamy ustnej [16] }\end{array}$ & $\begin{array}{l}\text { promowanie higieny jamy ustnej } \\
{[10032483]}\end{array}$ \\
\hline prowadzenie bilansu płynów [16] & $\begin{array}{l}\text { ocenianie równowagi płynów } \\
{[10037881]}\end{array}$ \\
\hline
\end{tabular}

Problem pacjenta: trudności w samodzielnym wykonywaniu czynności dnia codziennego

Diagnoza negatywna wg ICNP®: deficyt samoopieki [10023410]

\begin{tabular}{llll|l} 
Działania pielęgniarskie & $w$ & ujęciu & Interwencje wg ICNP® [7]
\end{tabular} 


\begin{tabular}{|c|c|}
\hline klasycznym & \\
\hline $\begin{array}{l}\text { ocenienie jaki jest zakres deficytu [8] } \\
\text { ocena zdolności samoopiekuńczych } \\
{[11]}\end{array}$ & ocenianie samoopieki [10021844] \\
\hline $\begin{array}{l}\text { pomoc podczas tych czynności, } \\
\text { których pacjentka nie potrafi } \\
\text { wykonać sama, np. toaleta ciała [8] } \\
\text { pomoc w toalecie wieczornej i } \\
\text { porannej całego ciała [16] }\end{array}$ & $\begin{array}{l}\text { asystowanie w czynnościach } \\
\text { toaletowych [10023531] } \\
\text { asystowanie w samoopiece } \\
\text { [10035763] }\end{array}$ \\
\hline $\begin{array}{l}\text { informowanie pacjentki o swojej } \\
\text { obecności i niesienia pomocy [8] }\end{array}$ & $\begin{array}{l}\text { zapewnienie ciągłości opieki } \\
\text { [10006966]; }\end{array}$ \\
\hline $\begin{array}{l}\text { edukacja rodziny chorej, co do } \\
\text { zakresu udzielenia pomocy pacjentce } \\
\text { [8] }\end{array}$ & $\begin{array}{l}\text { promowanie efektywnego procesu } \\
\text { rodziny [10036084] }\end{array}$ \\
\hline okazanie wsparcia i zrozumienia [11] & $\begin{array}{l}\text { wspieranie statusu } \\
\text { psychologicznego [10019161] }\end{array}$ \\
\hline
\end{tabular}

Problem pacjenta: obniżony nastrój

Diagnoza negatywna wg ICNPß: nastrój depresyjny [10022402]

\begin{tabular}{|l|l|l|}
\hline $\begin{array}{l}\text { Działania pielęgniarskie w ujęciu } \\
\text { klasycznym }\end{array}$ & Interwencje wg ICNP® [7] \\
\hline $\begin{array}{l}\text { podjęcie prób skrupulatnego } \\
\text { ustalenia przyczyn negatywnych } \\
\text { emocji występujących u pacjenta } \\
\text { [11] }\end{array}$ & $\begin{array}{l}\text { ocenianie postawy wobec choroby } \\
{[10024192]}\end{array}$ \\
\hline $\begin{array}{l}\text { ocena emocji towarzyszących } \\
\text { pacjentowi [11] }\end{array}$ & ocenianie nastroju [10038938] \\
\hline $\begin{array}{l}\text { okazanie pacjentowi wsparcia i } \\
\text { zrozumienia [11] }\end{array}$ & $\begin{array}{l}\text { zapewnienie } \\
\text { emocjonalnego [10027051] }\end{array}$ \\
\hline $\begin{array}{l}\text { zachęcanie rodziny do rozmowy z } \\
\text { chorym [9] }\end{array}$ & $\begin{array}{l}\text { promowanie wsparcia ra rany } \\
\text { [10036078] }\end{array}$ \\
\hline podkreślenie pozytywnych cech & dodawanie otuchy [10016480] \\
\hline
\end{tabular}




\section{Wnioski}

Rak płuc istotnie modyfikuje jakość życia pacjenta. Klasyfikacja ICNP® pozwala na projektowanie opieki pielęgniarskiej w oparciu o ujednoliconą terminologię.

\section{Bibliografia/Bibliography:}

1. Modlińska A, Kowalczyk A. Rak płuca - epidemiologia, obraz kliniczny oraz społeczne następstwa choroby. Psychoonkologia 2016;20(2):5765 [dostęp w internecie:https://www.termedia.pl/Rak-plucaepidemiologia-obraz-kliniczny-oraz-spoleczne-nastepstwachoroby,63,28257,1,0.html, data dostępu:12.12.19].

2. Kozierkiewicz A. (red). Strategia Walki z Rakiem Płuca. Instytut Gruźlicy i Chorób Płuc, Polska Grupa Raka Płuca, Polska Liga Walki z Rakiem. Warszawa 2017 [dostęp w internecie: https://ligawalkizrakiem.pl/images/content/Strategia\%20Walki\%20z \%20Rakiem\%20Pluca_FINAL.pdf, data dostępu: 14.12.2019].

3. Wojciechowska U., Olasek P., Czauderna K., Didkowska J. Nowotwory złośliwe w Polsce w 2014roku. Krajowy Rejestr Nowotworów. Zakład Epidemiologii i Prewencji Nowotworów, Centrum Onkologii - Instytut w Warszawie. Warszawa 2016 [dostęp w internecie: http://onkologia.org.pl/wp-content/uploads/Nowotwory2014.pdf, data dostępu: 12.12.2019].

4. Didkowska J., Wojciechowska U., Olasek P. Nowotwory złośliwe w Polsce w 2015 roku. Krajowy Rejestr Nowotworów. Zakład Epidemiologii i Prewencji Nowotworów, Centrum Onkologii - Instytut w Warszawie. Warszawa 2017 [dostęp w internecie: http://onkologia.org.pl/wp-content/uploads/Nowotwory_2015.pdf, data dostępu:12.12.2019]. 
5. Wojciechowska U., Czaderny K., Ciuba A., Olasek P., Didkowska J. Nowotwory złośliwe w Polsce w 2016 roku. Krajowy Rejestr Nowotworów. Zakład Epidemiologii i Prewencji Nowotworów, Centrum Onkologii - Instytut w Warszawie. Warszawa 2018 [dostęp w internecie:http://onkologia.org.pl/wpcontent/uploads/Nowotwory_2016.pdf, data dostępu:12.12.2019].

6. Krzakowski M., Jassem J., Antczak A. et al. Cancer of the lung, pleura and mediastinum. Oncol Clin Pract 2019; 15. DOI: 10.5603/OCP.2018.0056.

7. Międzynarodowa Klasyfikacja Praktyki Pielęgniarskiej [dostęp w Internecie:

https://www.icn.ch/what-we-do/projects/ehealth/icnp-browser, data dostępu: 06.12.19r].

8. Posieczek Z., Kobus E., Olszewska M., Galikowska A., Marzec I., Balcerak D., Budnik M. Wybrane aspekty opieki pielęgniarskiej nad pacjentem geriatrycznym z niedożywieniem. Journal of Education, Health and Sport2017;7(8):435-445.

[file://C:/Users/ThinkPad/AppData/Local/Temp/4753-17140-1PB.pdf, dostęp w internecie: 14.12.2019].

9. Nalewaj K., Zera A., Krupienicz A. Opieka nad pacjentem z niedrobnokomórkowym rakiem płuca- studium przypadku. Pielęgniarstwo Polskie 2018; 68 (2) [dostęp w internecie: http://www.wydawnictwo.ump.edu.pl/ojs/index.php/pp/article/view/327, data dostępu 14.12.2019].

10. Pielęgnacja Pacjenta w Chorobie Nowotworowej. Fundacja Hospicjum Onkologiczne św. Krzysztofa i Fundacja Tam i z Powrotem. Warszawa 2012 [dostęp w internecie: https://www.wco.pl/wpcontent/uploads/2015/08/poradnik_pielegnacja_internet_final.pdf. data dostępu: 05.12.19]. 